\title{
Analysis of the Difficulty of Study Programs in Unimed in the Development of Quality Assurance Based on Accreditation
}

\author{
Abdurahman Adisaputera ${ }^{1}$, Isda Pramuniati ${ }^{1}$, Syamsul Arif $^{1}$ \\ ${ }^{I}$ State University of Medan (Unimed), Indonesia \\ abdurrahmanadisyahputra@gmail.com
}

\begin{abstract}
Quality assurance efforts at higher education institutions today are largely determined by the value of accreditation obtained, both in the study program and higher education institutions. Of course various obstacles are faced for the implementation of accreditation. The purpose of this study is to describe and analyze the level of difficulty of the study program at Unimed in carrying out the development of an accreditation-based quality assurance program. The method used to achieve the objectives of the research is through a qualitative approach with descriptive methods. Based on the research that has been done, it can be concluded that the level of difficulty of the study program in Unimed in meeting the accreditation standards can be seen from the low acquisition scores in standards 4, 5 and 7 in the study program accreditation forms. The low value obtained from the standardaccreditation standards is influenced by the development of lecturers' resources in each study program to improve scientific publications in accredited national journals and / or reputable international journals, and the participation of the lecturers is a speaker at scientific forums such as national seminars and seminars international.
\end{abstract}

Keyword:Quality development; study program accreditation; accreditation

\section{Introduction}

Higher education accreditation is carried out as a form of responsibility of higher education providers to stakeholders, namely the community of users of the graduate about the state and efforts of higher education providers to produce graduates who meet the requirements in accordance with the provisions for each relevant education unit. recognition of the quality of higher education is determined by the status and accreditation rating.In order to realize transparent public accountability, universities must actively build an internal quality assurance system and can prove that the internal quality assurance system has been implemented properly and correctly. For this reason, universities must develop good governance and develop themselves as academic institutions on an ongoing basis. The National Higher Education Accreditation Board (BAN PT) (2008) provides a definition that accreditation is one form of evaluation (evaluation) of the quality and feasibility of a tertiary institution or study program conducted by an independent organization or body outside of a tertiary institution. The results of this accreditation will later become an acknowledgment that an institution or study program has met the quality standards that have been established, so that it is feasible to carry out its programs. 


\section{Review Literature}

In connection with the importance of current university accreditation, (Widayat et al: 2003) describes some of the benefits of accreditation of study programs, namely: (1) Providing assurance that accredited study programs meet the quality standards set by BANPT, (2) Encourage study programs to continuously improve and maintain quality, (3) Accreditation results can be used as a consideration in credit transfers, proposed assistance, and allocation of funds and obtaining recognition from interested institutions. Therefore, the quality assurance of higher education must be oriented to the planning, fulfillment, control and development of higher education standards in a consistent and sustainable manner.Improving the quality of the higher education study program is determined by the quality assurance system carried out by the institution. Based on Law No. 12 of 2012 concerning Higher Education, the Higher Education Quality Assurance System (SPM) covers two things, namely: Internal Quality Assurance System (SPMI) and External Quality Assurance System (SPME) or better known as Accreditation. Implementation of good internal quality is a must facilitate external quality assessment (Woodhouse, 2013: 3). Conversely, the SPME assessment results become a corrective input for the improvement of SPMI.

As stated by Ohanyan \&Harutyunyan (2016: 1) that higher education institutions are urged to develop an internal quality assurance system for external audit, accreditation and also to face competition in the education industry. However, the problem is that SPMI itself is generally not effective. The challenge actually comes from internal university stakeholders who are less concerned with the quality assurance process (Ryan, 2015: 7). In fact, the problem is crucial in the guarantee process is the lack of sensitivity of quality culture to stakeholdersinternal (Hodson \& Thomas, 2010: 101). The quality of the study program at a tertiary institution is the totality of the situation and the characteristics of the input, process and product or service of the study program as measured by a number of standards as a benchmark for assessment to determine and reflect the quality of higher education institutions. In other words, the accreditation standard is a benchmark that must be met by study programs. One standard of accreditation consists of several parameters (assessment elements) that can be used as a basis for measuring and determining the quality and feasibility of a study program to carry out its programs.Standards in the context of accreditation are the minimum criteria that must be fulfilled by the study program and become a benchmark for obtaining proper and quality recognition from the external evaluator institution that provides an assessment.

According to the Academic Manuscript of the Graduate Study Program Accreditation (BAN-PT, 2008), the accreditation standard consists of several parameters (key indicators) that can be used as a basis for (1) the presentation of data and information on the performance, circumstances and educational tools of undergraduate study programs, as outlined in the accreditation instrument ; (2) evaluation and. assessment of the quality of performance, the state and equipment of the education program study program, (3) the determination of the feasibility of the undergraduate study program to carry out its programs; and (4) the formulation of recommendations for improvements and the development of quality undergraduate study programs. The criteria are set based on standards, if the undergraduate study program has the same education equipment and standard or exceeds the standardthe study program has met the quality requirements. Conversely, if the standard 
cannot be met by the study program, the study program is said to have no interest or low performance.BAN-PT uses 7 (seven) undergraduate study program accreditation standards consisting of two standards on the commitment of undergraduate study programs to institutional capacity and five standards that support a commitment to the effectiveness of educational programs. The standards used for accreditation of undergraduate study programs in Indonesia are: a) Vision, Mission, Goals and Objectives, and Achievement Strategies, b) Governance, Leadership, Management System, and Quality Assurance, c) Students and Graduates, d) Resources human, e) Curriculum, Learning, and Academic Atmosphere, f) Financing, Facilities and Infrastructure, and Information Systems, and g) Research, Service / Community Service, and Cooperation.

\section{Methods of The Research}

The method used to achieve the objectives of this study is through qualitative methods, evaluation methods or evaluative studies with a qualitative approach through case studies and exploratory. Therefore, the data collection instruments consist of content formats, quality checklists, observation sheets, interview guidelines and documentation. This research is also a study of university quality management policies on the research umbrella / effective management field, with the aim of developing the development of Unimed quality based on accreditation standards. To achieve the objectives of this study, evaluation methods or evaluative studies are used with a qualitative approach through case studies and explorative studies.In an effort to collect research data in accordance with needs, four stages of policy research were carried out that referred to the stages prepared by Peter J. Haas and J. Fred Springer (1998: 22), namely: (1) Formulating problems; (2) Planning research; (3) Carry out research; and (4) Presenting the findings of the study and communicating recommendations.In the initial stage the researchers met key informants, leaders of university level quality management and then the selection of informants was obtained from key informants with snowball techniques or networks / sequences. Meanwhile a number of data retrieval techniques were used to collect data and information by filling in the filling format, quality checklist, observation sheet and $\mathrm{w}$ interviewguidelines. Data collection stages are: First, documentation studies related to Unimed's development policy products. Second, collecting data and information about existing Unimed quality standards. Third, collecting data and information related to the study of quality development based on Study Program accreditation.In order to achieve the research objectives as mentioned in the previous section, data analysis carried out is based on an interactive model, meaning that the analysis is carried out interactively and continuously. The interactive model can be described with a framework that summarizes three sets of analysis stages, namely: (1) data reduction; (2) displaying data, and; (3) draw conclusions and verification (Miles and Hubberman, 1994).

\section{Research Results and Discussion}

The value of accreditation obtained by the college is the accumulation of values in all indicators of university performance. The value of the performance indicator is the numerical value and other forms of information that explain or measure progress in achieving the 
mission, goals and objectives of a particular educational unit (BAN-PT, Evaluation Guidance Program Study Program, 2005). Accreditation status of a university reflects the performance of the tertiary institution concerned, and can be a benchmark that describes the quality, efficiency, and relevance of a study program held. The following is a description of the difficulties of each study program incorporated into the five faculties in Medan State University in implementing the quality assurance system based on the results of the study program accreditation.

\subsection{Quality Assurance in the Language and Arts Faculty (FBS) Unimed Based on Accreditation}

Currently, 9 out of 10 study programs at FBS Unimed have been accredited by BANPT. The results of the accreditation of each study program based on the value of each accreditation standard can be seen in the figure below.

Figure 1. Study Program Accreditation Results at the Unimed Faculty of Language and Arts
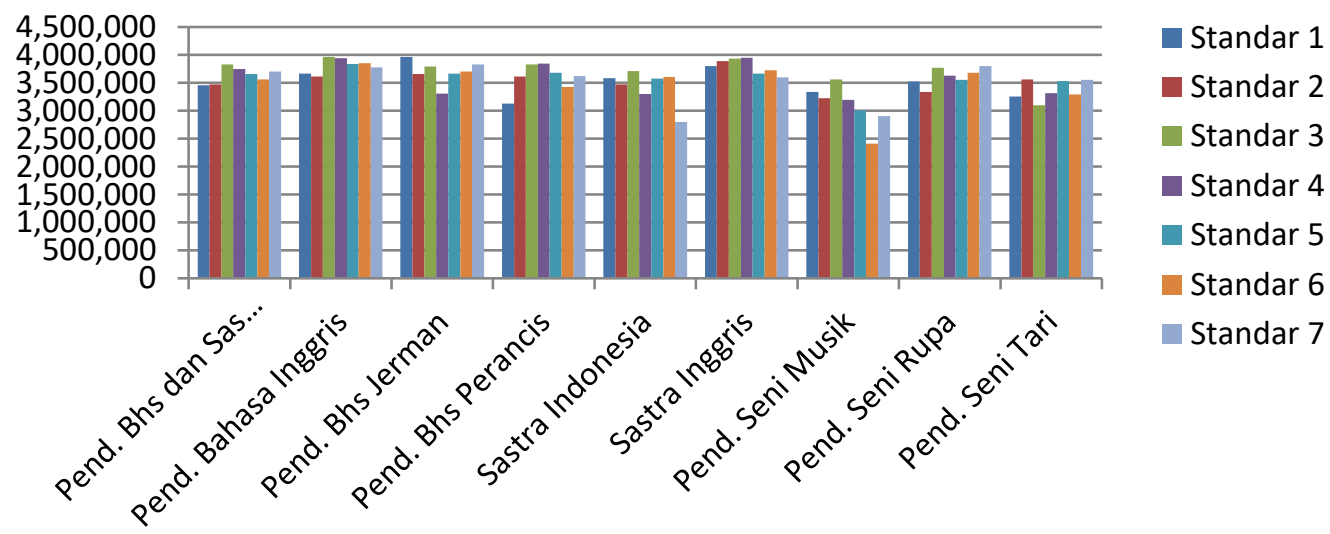

Based on the figures outlined above, the level of difficulty of the study program at FBS Unimed in meeting the standards of accreditation is an obstacle to obtaining the maximum accreditation value found in standards one, two, six and seven. The lowest value obtained in standard one is 3,127 by the French Language Education Study Program, while the highest score is 3,961 by the German Language Study Program. While other study programs received good grades, namely Indonesian Language and Literature Education, 3,460, 3,669 English Education, Indonesian Literature Study Program 3,585 Music Arts Education Study 3,335, 3,527 Fine Arts Education Study Program, and 3,525 Dance Education Study Program. The information traced to the values obtained in this standard is the difficulty of the study program in harmonizing the documents prepared in carrying out the mechanism of preparing the vision, mission, goals, and objectives of the study program.

\subsection{Quality Assurance at the Faculty of Mathematics and Natural Sciences (FMIPA) Unimed Based on Accreditation}

The Unimed Faculty of Mathematics and Natural Sciences (FMIPA) is currently caring for 8 study programs, including 4 education-based study programs and 4 other noneducation-based study programs. The results of the accreditation of each study program based on the values in each accreditation standard can be seen in the picture below . 


\section{Figure 2. Results of the Study Program Accreditation in the Mathematics Faculty and} Natural Sciences (FMIPA) Unimed

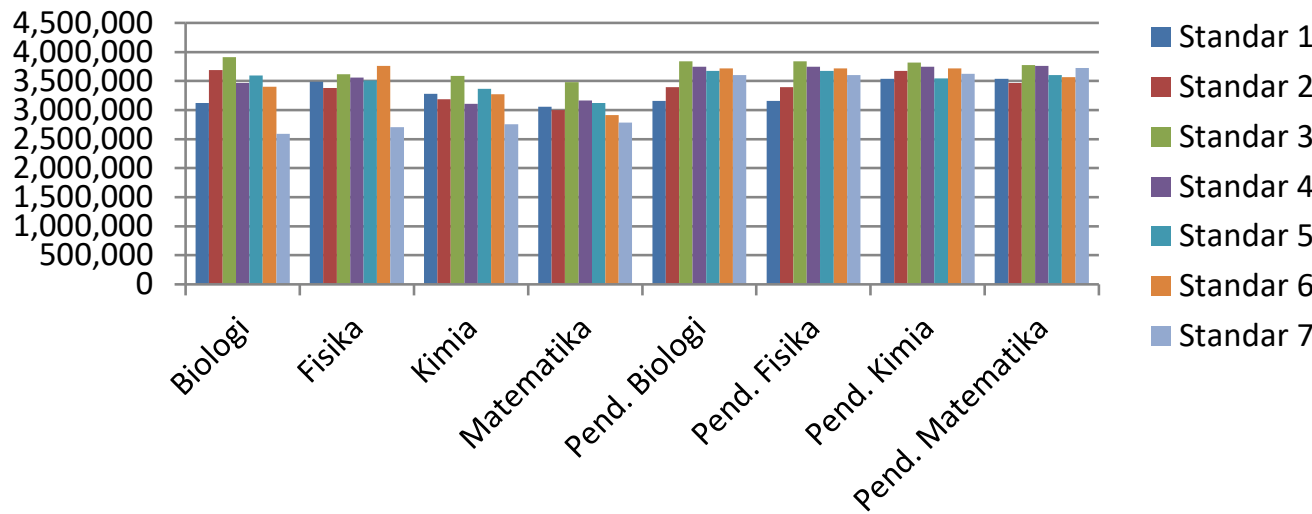

Based on the data presented in the figure above, the best accreditation value of study programs at FMIPA Unimed is found in the standard 3 of Biology Study Program, namely 3,911. Meanwhile, the lowest accreditation value is found in standard standard 7. The standard value of 7 obtained by Biology Study Program is 2,588, Physics Study Program 2,702, Chemistry Study Program 2,752, Mathematics Study Program 2,781, Biology Education Study Program 3,604, Physical Education Study Program 3,604, Chemistry Education Study Program 3,623, and Mathematics Education Study Program 3,727. The low publication of research results in non-education-based study programs is a major obstacle in increasing the standard form accreditation value 7 . In addition to the standard 7 accreditation forms, the next level of difficulty faced by study programs at FMIPA is the standard 4 and 5 accreditation forms. obtained Chemistry Study Program 3,103 in standard 3 and the value obtained by Mathematics Study Program in standard 5 is 3,102.

\subsection{Quality Assurance in the Faculty of Education Science (FIP) Unimed Based on Accreditation}

The existence of the Unimed Faculty of Education (FIP) is very important for the people of North Sumatra. This can be seen from the interest of prospective new students in competing to become students in this faculty. One of the most popular study programs in the community is the PGSD Study Program. Based on the results of research Sugiyono, et al. (2012) showed that of the 15 PGSD Study Programs that were the sample of the study, the PGSD Unimed Study Program ranked first in terms of ratio and the number of tightness of new student selection. The tightness of selection at the PGSD Study Program was Unimed with a ratio of 1: 56.8. In 2016 the number of applicants who enrolled in the PGSD Study Program for the SBMPTN path was 3,969, while the capacity was only 128 students.In addition to the PGSD Study Program, Unimed FIP also cared for Counseling Guidance Study Programs, PAUD Teacher Education, and Non-Formal Education. The results of the acquisition of accreditation scores for each study program based on the values in each accreditation standard can be seen in the figure below. 
Figure 3. Results of the Accreditation of the Study Program in the Unimed Faculty of Education (FIP).

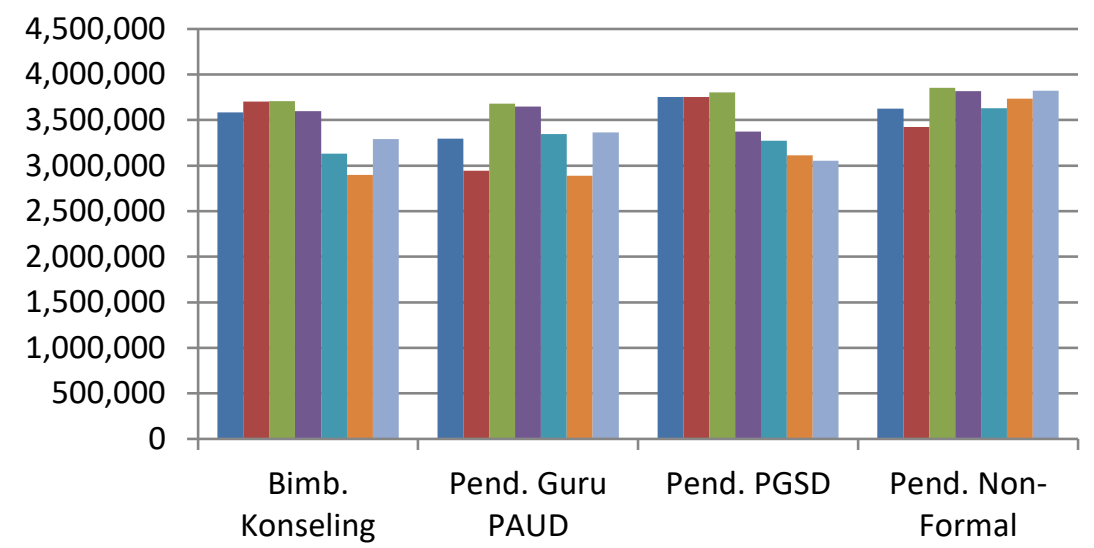

Based on the value data for each accreditation standard form described in the figure above, the best accreditation value is found in standard 4 by Non-Formal Education Study Program, namely 3,817. Meanwhile, the lowest accreditation value is found in the standard standard 2. The standard value 2 obtained by the Non-Formal Education Study Program is 3,424, Prodi PGSD3,752, PAUD Teacher Education Study Program 2,945, Counseling Guidance Study Program3,702. 2 accreditation forms based on the results of the analysis of the acquisition of these values are in the study program efforts to ensure the sustainability of the program in implementing quality management improvements, improving the quality of graduates, and achievement of obtaining competitive grants.

\subsection{Quality Assurance at the Faculty of Social Sciences (FIS) Unimed Based on Accreditation}

There are four study programs managed by the Faculty of Social Sciences (FIS) Unimed, namely Anthropology Education Study Program, Geography Education, Citizenship Education, and Historical Education. based on the value of each accreditation standard. This value can be seen in the picture below.

Figure 4. Study Program Accreditation Results at the Unimed Faculty of Social Sciences (FIS)
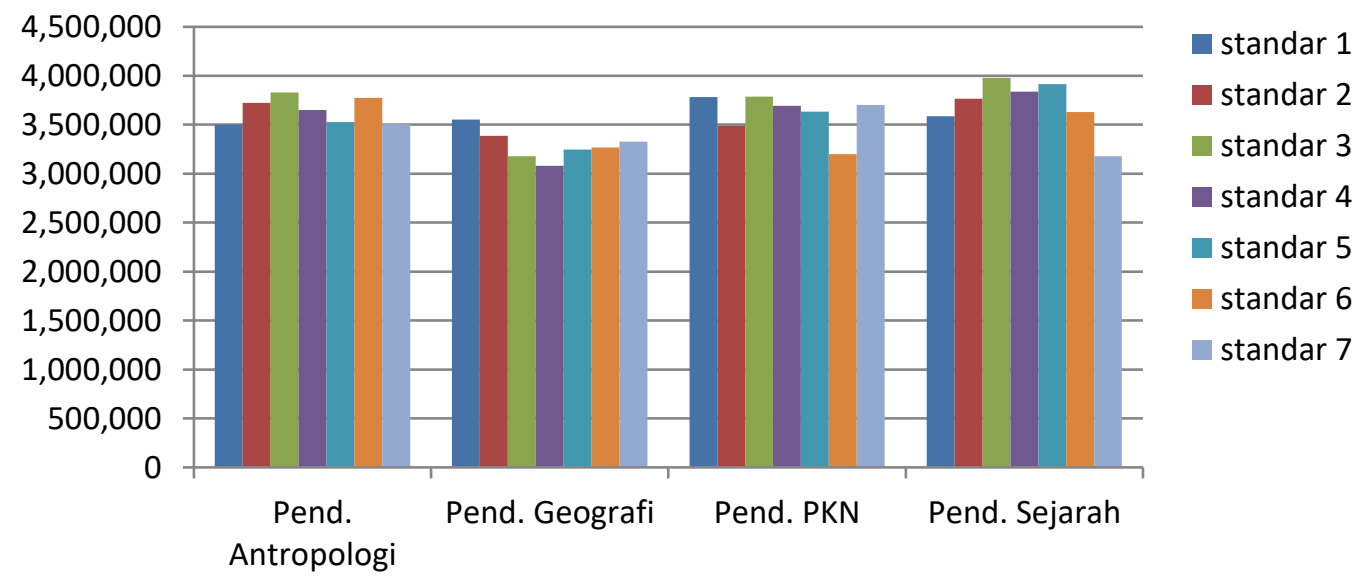

standar 7 
Based on the data presented in the figure above, it can be seen that the implementation of accreditation-based quality assurance activities has gone well. The acquisition of scores on each standard accreditation form in each study program reaches more than 3.0. The highest value is found in the standard 3 accreditation forms, namely 3,978 by the History Education Study Program. The values that were not much different were also obtained by 3 other study programs, namely Anthropology Education Study Program 3,827, Geography Education Study Program 3,178, and Citizenship Education Study Program 3,785.

\subsection{Quality Assurance at the Faculty of Sports Science (FIK) Unimed Based on Accreditation}

The Faculty of Sports Sciences (FIK) Unimed currently maintains 3 study programs, namely: Sports Science Study Program, Sports and Recreation Physical Education Study Program, and Sports Coaching Education Study Program. picture below.

\section{Figure 5. Study Program Accreditation Results at the Unimed Faculty of Sports Science} (FIK)

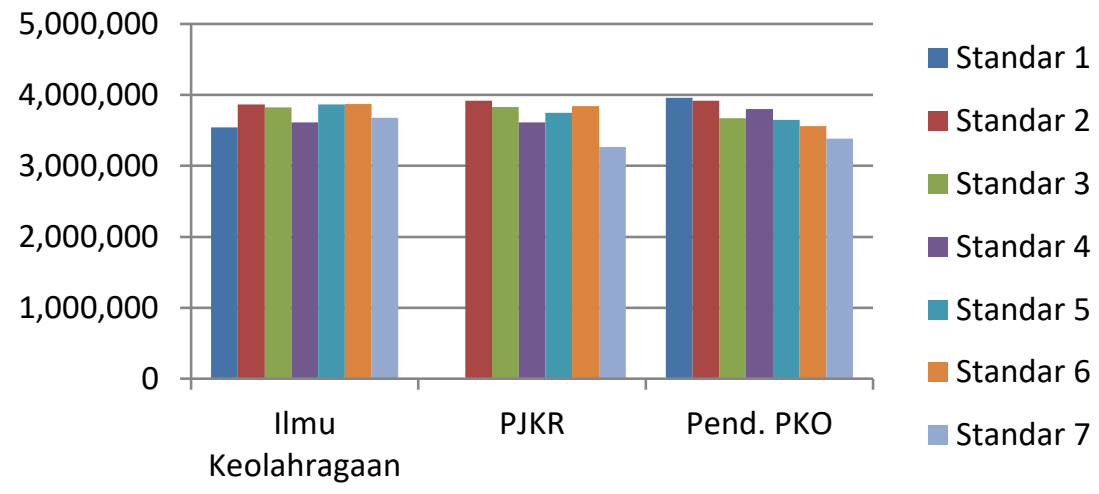

Based on the data presented in the figure above, the accreditation value is best found in the standard 1 for PJKR Study Program (Sports Physical Education and Recreation), namely 4. Two other study programs also get the maximum score for standard 1, which is 3.54 for the Sports Science Study Program. and 3,961 for Sports Coaching Education Study Programs. Meanwhile, the lowest accreditation value is found in standard standard 7. The standard value of 7 obtained by the PJKR Study Program (Sport Physical and Recreational Education) is 3.26 .

\subsection{Quality Assurance in the Faculty of Engineering (FT) Unimed Based on Accreditation}

The Unimed Faculty of Engineering (FT) is currently caring for 9 study programs, namely: Cooking School Education Study Program, Fashion Design Education, Cosmetology Education, Building Engineering Education, Electrical Engineering Education, Medin Engineering Education, Automotive Engineering Education, Mechanical Engineering D3, and Engineering D3 Civil. The results of the accreditation of each study program based on the value of each accreditation standard can be seen in the figure below. 


\section{Figure 6. Study Program Accreditation Results at the Unimed Faculty of Engineering} (FT)

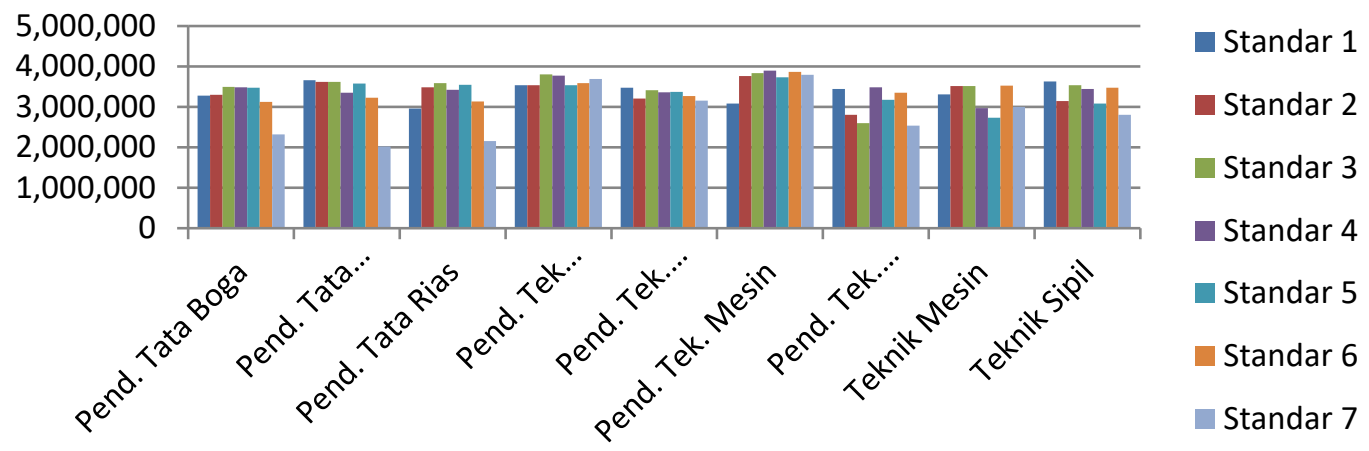

Based on the data presented in the figure above, it can be seen that the implementation of accreditation-based quality assurance activities has gone well. The acquisition of scores on each standard accreditation form in each study program reaches more than 3.0. However, there are some study programs that need to pay attention to the quality of their study program quality management at standard 7. Tata Boga Study Program, Fashion Design Study Program, Makeup Program Study Program still gets a score of 2.5 on the standard 7 so it is necessary to increase the publication of their lecturers' research results in scientific journals and proceeding national / international scientific meetings.

\section{Conclusion}

Based on the research that has been done, it can be concluded that the level of difficulty of the study program in Unimed in meeting the accreditation standards can be seen from the low acquisition scores in standards 4,5 , and 7 in the study program accreditation forms. The low value obtained from the standard-accreditation standards is influenced by the development of lecturers' resources in each study program to improve scientific publications in accredited national journals and / or reputable international journals, and the participation of the lecturers is a speaker at scientific forums such as national seminars and seminars international.

\section{REFERENCES}

Widayat, dkk. (2013). Analisis Kualitas Program Studi Perguruan Tinggi dalam Mendukung Pendapaian Koridor Ekonomi Indonesia. Jakarta: Pusat Data dan Statistik Pendidikan (PDSP) Kementerian Pendidikan dan Kebudayaan.

Nurlaqim, S. A., dkk. (2014). Peranan Perguruan Tinggi dalam Meningkatkan Kualitas Pendidikan di Indonesia untuk Menghadapi ASEAN Community. SHARE: SOCIAL WORK JURNAL. 6 (2), 154-272.

Gumiandari, S. (2013). Komitmen Pimpinan dalam Pelaksanaan Penjaminan Mutu Perguruan Tinggi. Jurnal Holistik. 14 (2), 27-56.

Peter J. Haas dan J. Fred Springer (1998: 22)(Miles dan Hubberman, 1994).

Woodhouse, D. 2013. Global Trends in Quality Assurance. Quality Approaches in Higher Education, (4)2. 
Ohanyan,A.\& Harutyunyan, H. (2016). TheRole of Internal Audit in ContinousImprovement of Quality ManagementSystem at Private HE Institutions: ACase Study of Eurasia InternationalUniversity (Armenia). Journal of Business \& Financial Affairs, 5(1), 110.Doi:10.4172/2167-0234.1000170.

Ryan, Tricia. (2015). Quality Assurance inHigher Education: A Review ofLiterature. Higher Learning ResearchCommunications, 5(4), 15-24. http://dx.doi.org./10.18870/hlrc.v5i4.257 